NBER WORKING PAPER SERIES

WHY DO EMPLOYERS PAY FOR COLLEGE?

Peter Cappelli

Working Paper 9225

http://www.nber.org/papers/w9225

\author{
NATIONAL BUREAU OF ECONOMIC RESEARCH \\ 1050 Massachusetts Avenue \\ Cambridge, MA 02138 \\ September 2002
}

The views expressed herein are those of the author and not necessarily those of the National Bureau of Economic Research.

(C) 2002 by Peter Cappelli. All rights reserved. Short sections of text, not to exceed two paragraphs, may be quoted without explicit permission provided that full credit, including $(\mathrm{C}$ notice, is given to the source. 
Why Do Employers Pay For College?

Peter Cappelli

NBER Working Paper No. 9225

September 2002

JEL No. I2, J2

$\underline{\text { ABSTRACT }}$

Employers routinely provide financial support for their employees who pursue postsecondary education despite the fact that it represents perhaps the classic example of a "general skill" that costs the employer money and raises the market wages of employees who possess it. The analysis below examines why employers provide such support, and the results suggest that employees do not pay for tuition assistance through below market or training wages, the typical arrangement for funding general skills training. Instead, tuition assistance appears to select better quality employees who stay on the job longer, at least in part to keep making use of that benefit.

\author{
Peter Cappelli \\ The Wharton School Center for Human Resources \\ 308 Vance Hall \\ 3733 Spruce Street \\ Philadelphia, PA 19104-6358 \\ and NBER \\ E-mail: cappelli@wharton.upenn.edu
}




\section{Why Do Employers Pay for College?}

\section{Introduction:}

The tuition assistance that employers provide for their employees who pursue postsecondary education is a ubiquitous and crucial element in the resources that support students. It is not obvious why employers provide such support, however, because post-secondary education represents perhaps the classic example of a "general skill" that raises market wages. The analysis below examines why employers provide support for the education of their employees and may shed some light on the more basic question as to why employers invest in the general skills of their employees.

\section{The Nature of Employer Support:}

A range of evidence suggests that employer assistance represents a central part of the portfolio of resources that pay for post-secondary education. The American Council of Education estimates, for example, that roughly 20 percent of graduate students are receiving some financial assistance from their employer to attend school (cited in Babson 1999), and roughly 6 percent of the much bigger pool of all undergraduates receive such aid as well (Lee and Clery 1999). As many as one-third of undergraduates in fields like business and engineering receive financial assistance from their employers. If one looks only at adult students, who are more likely to be employed when they are in school and therefore have the possibility of receiving aid from employers, data from the National Center on Educational Statistics' Adult Education Survey found that 24 percent of adults in post-secondary education programs of the kind that offered credentials (e.g., degrees or certificates) were receiving tuition assistance from 
an employer, and 53 percent were either receiving tuition support or paid time off from work (Hudson 2001). The Bureau of the Census estimates that financial assistance from employers is the most common source of financial aid. The average level of employer-provided assistance per recipient was equal to about one-third of the average annual cost paid by post-secondary students (Bureau of the Census, 1994). ${ }^{2}$

The extent to which employers provide assistance can be measured more directly from surveys of employers, and those results suggests that employer-provided support is ubiquitous. For example, a 1992 survey by Coopers and Lybrand of 209 employers found 86 percent offering tuition reimbursement plans (BNA 1992a); a 1993 Hewitt Associates survey of 858 employers also found 99 percent using tuition reimbursement and about 6.5 percent of all employees in those firms taking them up at any point in time (Hewett Associates 1993); another survey the same year of 335 companies reports that while most companies offered tuition reimbursement, 93 percent went further and offered other types of financial assistance for education as well as tuition (IFEBP 1993). A more recent 2002 survey by the Society for Human Resource Management of 510 employers found a somewhat lower number, 79 percent offering educational assistance of various kinds (SHRM 2002). These surveys are based on samples of convenience and of very large employers, however, and therefore may not accurately represent the true level of participation among all employers. The data used here (see below) will report levels somewhat below these estimates but still suggest that a substantial majority of employers offer such plans. Whichever figures one uses, it is clear that most employers do help pay for their employees to receive post-secondary education.

\footnotetext{
${ }^{2} \mathrm{~A}$ calculation of tuition assistance as a proportion of total post-secondary expenses must be somewhat indirect: Census calculates that half of all students (including, of course, those who are not working) receive some aid and one-third of students who received aid got some from their employer. Therefore,
} 
This conclusion is interesting because it is something of a surprise that any employers should offer such support, let alone that most employers do. Post-secondary education represents the classic example of the type of investments in employees that we would not expect employers to make because the skills and knowledge it produces are general skills useful to other employers. As Becker (1964) first made clear, the benefits of such general skills flow to the employees who possess them and not to the employers who provided them: Because these general skills are useful elsewhere, the current employer has to pay the market wage for employees who have them or risk losing those workers to competitors who will pay that market wage. The employer who pays for the cost of general skills training would then also have to pay the employee a higher wage equal to the improvement in marginal product that such training generated, making it difficult or impossible to recoup that investment. The skills provided through post-secondary education are arguably the most general as they enhance many basic skills, such as communications and analytic skills, which are broadly useful. Even occupationally specialized programs, such as nursing or computer programming, are valuable to a great many employers. Course work tends to be reasonably standardized, and transcripts certifying knowledge of at least some level of the material being taught are readily available to potential employers.

There are clearly variations in the level and type of support that employers provide to their student employees, but the main type of support is tuition assistance to pay some or all of the direct costs of coursework. Surveys of employers who offer such plans find that, while there is considerable variation across plans, the benefits are not trivial and are often quite generous. ${ }^{3}$

roughly 17 percent of all students received employer assistance. If employers paid one-third of the costs for these students, then they are paying about 5 to 6 percent of all post-secondary expenditures.

${ }^{3} 77$ percent of employers pay expenses beyond tuition (seven percent even pay for parking), and 72 percent have no limit on the number of courses that employees can take (Hewitt 1998). The average 
Even where the skills being acquired are useful in current jobs, the benefits associated with the employee's increased marginal productivity should flow to the employee as long as those skills are general and useful elsewhere. Nor is it the case that employers who need certain general skills in their workforce have to send their current employees to college to get them. The obvious alternative is simply to hire employees who already have those skills. The employer has to pay the market wage for general skills when they hire such workers, but at least they do not have to pay for the skills and pay the market wage as they presumably do when they provide tuition assistance for current employees. So the question remains, why do employers do it? ${ }^{4}$

\section{Why Employers Support General Skills:}

Evidence from employee surveys suggests that most training may be general in the broad sense of being useful elsewhere (Barron, Berger, and Black 1999). There is now a large literature attempting to explain why employers in fact provide general skills training of all kinds, and some of those explanations may apply to employer support for post-secondary education as

employer payment through tuition assistance plans is $\$ 3906$ per year while the modal payment is $\$ 5,000$ (IFEBP 2002). Eighty percent of employers in this same survey allow their employees to take any courses regardless of subject matter or eventual degree, therefore in some cases paying for skills that have no benefit to them. The others restrict the content in various ways, typically to programs and courses that have some relevance to the company and the employee's work there. Such restrictions make it more likely that the skills the employees acquire will be of some use to the employer.

${ }^{4}$ Perhaps the simplest explanation might be that tuition assistance is just a tax-free benefit that employers offer as a form of cost-effective compensation. Employee payments for their own tuition are only tax deductible under limited circumstances (i.e., for coursework directly related to their job), but employers can provide their employees with up to $\$ 5250$ toward tuition costs without the employees having to pay income tax on those benefits. Similarly, the employers can avoid paying FICA contributions on those payments that they would otherwise have to pay on compensation, arrangements known as Section 127 Benefits. The Taxpayer Relief Act of $1997 \mathrm{kept}$ all undergraduate tuition reimbursements tax exempt to recipients but made graduate reimbursements taxable unless they were for courses related to work, a criterion that has been interpreted broadly. But any utility in terms of additional compensation for the workforce would be greater for other employee benefits that are used by more employees, such as expanded healthcare. So it is not at all obvious why employers who were motivated to offer tax-free compensation would choose this benefit as opposed to others. 
well. Ultimately, employers have to recoup the investment in training through a gap between what workers produce and what they are paid. The question is how that happens.

Among the possible explanations is the argument put forward by Katz and Ziderman (1990) suggesting that, in practice, information about general skills provided by one's employer is not readily available to other employers. While such skills may be valuable to other employers, if they cannot be easily identified by other employers, then other job offers will not be forthcoming. Employers can therefore provide general skills training because those skills will raise the productivity but not the marketability and wages of their employees.

This explanation does not seem to apply to post-secondary education, however, because such education creates general skills that are easily identifiable in the market place. Indeed, education is probably the most readily identifiable credential for skills because it is widely recognized not only by employers but by virtually everyone. The credentials are issued by independent organizations, typically by colleges and universities, which are certified in various ways to ensure that the skills being taught conformed to standardized criteria. Indeed, postsecondary institutions sometimes compete with each other on their ability to raise the wages of their students, and the relatively higher wages of those who attend college (especially for those who graduate, given that degrees represent the clearest signal of skills to the market) is one of the most important stylized facts in the labor market. So it seems unlikely that the decision to help pay for the education of employees can be explained by asserting that the skills provided cannot be observed in the market.

Arguably the best-known explanation for funding general skills training and the one outlined by Becker is to have the employees pay for it explicitly by accepting "training" wages that are below their marginal product, and typically below the market wage, while they are being 
trained. Apprenticeship-type arrangements are the best example, and there are many descriptions of similar arrangements (see, e.g., Leuvan, 1999).

Other studies have shown that workers receiving general skills training do not necessarily receive lower training wages (see Bishop 1996; Baron, Berger, and Black 1997), however, and there are reasons for believing that training wages are unlikely to be the explanation for tuition assistance. There are no arrangements with which I am familiar in companies to hold down or reduce wages explicitly while employees are receiving tuition benefits as there are with tuition programs. ${ }^{5}$ So the question would be whether tuition benefits are used at a point where wages are otherwise held below their productivity, such as at the beginning of their career as many models assume (whether there is evidence that wages are in fact below marginal products then is, of course, a separate empirical question).

There are at least two reasons for thinking that this is not the mechanism that funds tuition assistance. First, most employers prohibit access to tuition benefits for new hires, when one would think of the employees as being "trainees" who are still learning their jobs. Fiftyseven percent make employees wait a year or more of service before they can receive such benefits (IFEBP 2002). That may not seem like a significant delay, but it is important to remember that most employees do not stay long with a given employer: Over the past twenty years, one in five employees had tenure of less than one year (Jaeger and Stevens, 2000), and forty-five percent stay four years or less (Neumark, Polsky, and Hansen 2000).

Second and most important, once employees are eligible for these programs, with few exceptions (e.g., approval required for certain courses) the employees themselves decide when to

\footnotetext{
${ }^{5}$ I put this question to a group of 41 human resource managers at the 2002 Society for Human Resource Management (SHRM) Annual Conference program on business strategy (June 22 2002). None of their companies had any arrangements where it was possible to explicitly lower the wages of workers using TAPs, and none had heard of any arrangement like those elsewhere.
} 
use the benefits. The typical model of tuition assistance, where employers pay some or all of the tuition costs and employees attend classes on their own time, cannot be used for employermandated training because of various legislative restrictions governing training and tuition assistance. (If the training is required and the employer mandates it, then the employer must pay the full cost of the training, provide it during working hours, and pay non-exempt workers their full wage while receiving the training. See footnote 14.) After meeting the minimum tenure requirements, employees can use tuition assistance whenever they want. So the question is whether employees voluntarily and systematically happen to use them at points when we might believe wages are otherwise held down. Back-loaded models of compensation assert that this period would be at the beginning of their career.

There are no systematic data on tenure and use of tuition plans, but I investigated through contacts with human resource departments the pattern of usage at several organizations. These may be representative of arrangements in the population. At my University, for example, the benefits office reports that the average employee who uses tuition benefits for their own education has five years of tenure while the average tenure for all employees is nine years. United Technologies reports that their average tuition benefit recipient has five years with the company; average tenure there is closer to 15 years. Xerox Copier Division says that their average user is over 30 years of age while the average worker in the Division is closer to 40 . Harleysville Insurance, which has a remarkable 30 percent of all employees currently using tuition assistance, reports that the distribution of usage by tenure and age is roughly proportionate to that of the workforce as a whole. All of these organizations note that there is a wide distribution of use by age and tenure levels - some of the oldest and most senior employees 
use them as well. And employees seeking degrees may use the plans for many years, given that they are by definition attending school part time and may be seeking degrees.

Tuition assistance users may be somewhat younger and less senior than the workforce as a whole, but they are not new hires, and many senior workers use them as well. Further, the data presented earlier suggests that only a fraction of the workforce is using these benefits at any point in time. It is extremely difficult to imagine any wage structure that would hold down wages selectively for workers who use these plans without holding down effectively most of the wages for the firm. It might be, of course, that employers who use these plans systematically have below-market wages, a possibility that is examined below.

Acemoglu and Pischke (1999) put forward a different explanation, that workers pay for general skills after the fact by having marginal products that exceed their wages. Their explanation relies on compressed wage structures where wages for higher skilled workers are artificially held down relative to their own marginal products. Market imperfections in various forms could prevent wages from rising and make it possible for the employers to recoup tuition investments by having worker productivity exceed their wages. Given that tuition assistance programs operate so broadly across the economy and that employees use them at any point in their career, it seems unlikely that market imperfections as one usually thinks of them (e.g., collective bargaining agreements) would explain their wide-spread use. One type of market imperfection, imperfect information, may be a promising explanation for the use of tuition assistance in that it could be wide-spread enough to explain the results.

Specifically, tuition assistance may create private information by sorting out heterogeneity and information asymmetries among job applicants. We know that applicants who are interested in being trained may be systematically better workers in ways that are useful to the 
employers as compared to employees who do not have that interest. Acemoglu and Pischke (1998) and Autor (2001) provide evidence that firms offering general skills training do attract better quality workers and argue explicitly that self-selection mechanisms are part of the story. Employers who offer training may therefore have an advantage in recruiting over those who do not because better quality applicants self-select to apply for those jobs (Stevens 1994).

Self-selection seems especially applicable to tuition assistance because the general skills provided by post-secondary education are the ones that employees understand will benefit them most. Poorer-quality applicants who lack the ability, discipline, or motivation to take succeed in post-secondary education will see no advantage from taking jobs with such a benefit (unlike most employer-provided general skills training, it is possible to fail post-secondary courses). And unlike most other employee benefits, employees must share in the costs of using tuition assistance through an investment of their time and effort, typically outside of work hours, as well as some of the financial costs (few plans pay the entire cost of tuition, fees, books, etc.). So the usual requirement of signaling models, that there be a "separating equilibrium" whereby it is easier or more desirable for high ability applicants to signal their ability, seems to apply here. A lower initial or "training" wage as in other models of general training may not be needed to dissuade lower ability workers from applying.

Uncovering better quality workers could allow firms to earn a return if the information about the superior abilities of those workers is not publicly available: Their market wage does not rise if the information is not readily available even though their marginal product is higher. ${ }^{6}$

\footnotetext{
${ }^{6}$ It is possible that merely being hired at a firm that offers tuition assistance could send a signal to other employers that one is a better worker. But quitting that first firm to take advantage of offers from other firms could also send a negative signal about one's capabilities (e.g., that the employee had problems at work) that makes them less attractive. As Greenwald (1986) observed, the fact that the first employer knows who is a good worker, presumably keeping the good ones and firing the poor ones, generates adverse selection in the outside or second-hand market.
} 
If their productivity is above market levels, employers could earn a margin on them even while paying the market wage. Employers may even have an incentive for rent sharing, raising wages somewhat above the market rate, in order to induce these good workers to stay with the firm.

Turnover should be lower as well where employees use tuition assistance. Part of the explanation is obvious: As noted above, many employers require that employees be with the firm for some period before they receive tuition assistance. A smaller percentage require employees to sign contracts that make them reimburse the costs of the tuition benefits should they quit before some specific date. About 20 percent of U.S. employers have such requirements, and the average length of stay required is six months (IFEBP 2002). The requirement across the population of all employers who offer tuition assistance, therefore, would average out to roughly 36 days. Together these arrangements no doubt have some effect on increasing average tenure and reducing turnover.

The more important explanation for lower turnover is what one might label an "efficiency wage" mechanism: Employees stay with the firm longer because they want to keep using the tuition assistance benefit to complete their education, a process that could take many years. Receiving a post-secondary education is a time-consuming process, especially if one is going to school while working. The shortest course that is typically possible, a single semester class of roughly 14 weeks, is more than double the 36 day requirement noted above, and the coursework required for even an Associate's Degree could easily exceed the tenure of the average employee. If employees who use tuition assistance are tied to their firms during the period when they are using the plans, then employers are able to hold down wages somewhat during that period, at least relative to worker's marginal productivity. And the common requirement to serve some 
period of time before tuition assistance can be used prevents employees from finishing their education by jumping to a competitor.

A related possibility is that firms that offer tuition benefits and the workers who select into them are distinctive in ways that create better matches between jobs and workers. A good fit or "match" between distinctive jobs and distinctive workers leads to higher performance without necessarily raising market wages because the match is not transferable elsewhere. Employers have an incentive to share some of the rents generated by this better performance in order to help retain the good matches, so wages rise above market levels and turnover falls as a result (Jovanovic 1979; see also Bowlus 1995 for wage effects and Hersch and Reagan 1990 and Simon and Warner 1992 for tenure effects). Empirical models of match quality have fallen somewhat out of favor, however, because it is difficult to identify the mechanisms through which superior matches would take place and essentially impossible with most data to examine the quality of matches per se. And the predictions of higher wages and lower turnover are often consistent with other models. In this case, the selection/efficiency wage argument above is simpler and makes the same predictions. While we cannot explore the match quality hypothesis explicitly, it is worth bearing in mind that it could present an alternative interpretation for the analyses below.

\section{A Simple Theoretical Model of Tuition Assistance:}

In the model below, workers who have greater ability and motivation self-select into firms with tuition assistance plans. Their marginal productivity, other things equal, is above average levels in the market. Information about their superior ability is at least not immediately or perfectly available to other firms (the signal comes when they actually begin using tuition 
assistance), and so their market wage does not rise to the level of their marginal productivity. Because their productivity is above market levels, employers can pay them the market wage and still earn a margin on their performance. (The workers might have been willing to accept wages below market levels in return for tuition benefits, but the fact that employers are earning a return on the workers even at market levels sufficient to fund the tuition benefits combined with labor market competition among employers pushes the wages higher.) The employees who receive tuition assistance are tied to the firm for many years. In part requirements of the tuition assistance plans may tie them there, but mainly they stay in order to make use of the benefits and receive their education, a process that can take years. Once they finish their education, their market wage rises to reflect the level of their new general skills and their greater ability and motivation as signaled by essentially working their way through school using tuition assistance. At that point, their market wage rises to their true marginal productivity, and the employer no longer earns a return that could be used to pay off the tuition benefits.

Consider the match between a firm and its employees where one looks at match quality from the perspective of the firm, instead of the usual focus at the individual level, where the concern is with the average quality of matches across the workforce.

The match quality $m$ depends on a firm's general recruiting and work practices and on its educational policy, including tuition reimbursement for general skills training in the form of post-secondary education. Let $t$ denote tuition reimbursement for employees, and $i$ denote the combination of all other characteristics of a firm that affect its overall match quality. It is assumed that the two partial derivatives of $m(t, i): m_{t}(t, i), m_{i}(t, i)$, and the cross second derivative $m_{t i}(t, i)$ are all positive. 
Because $i$ defines many of the attributes of a firm, it no doubt has an important influence on recruiting and on the average match quality of its employees. Tuition reimbursement encourages employees to increase their stock of general skills and of human capital more broadly, which increases their ability to perform better on the job. At least some part of the cost of acquiring those general skills is borne by the student/employee through time and effort spent learning outside of working hours. Assume also that firm-specific skills are seen as compliments to general skills and that higher levels of general skills induce the firm to invest more in specific training. The more crucial the human resources are to a firm's success, the bigger the influence that tuition reimbursement will have on the firm's overall productivity.

Let $h_{0}$ be an employee's initial human capital when joining the firm. The tuition reimbursement encourages the employee to increases his/her human capital to $h=h_{0}+t$. Suppose all competing firms have the same technology represented by a production function $f(h)$ without loss of generality. We index each firm by its characteristics $i$ so that firm $i$ 's production function is $m(t, i) f(h)$. The wage rate is denoted by $w_{\mathrm{i}}$. The objective function of a firm $i$ is

$$
\max m(t, i) f(h)-w_{\mathrm{i}} h-c(t)
$$

with respect to $t$, taking other parameters as given. Here $c(t)$ is the cost of tuition reimbursement.

The first order condition about $t$ is

$$
\begin{aligned}
& m_{t}(t, i) f(h)+m(t, i) f^{\prime}(h)-w_{\mathrm{i}}-c^{\prime}(t)<0 \text { if } t=0 ; \\
& m_{t}(t, i) f(h)+m(t, i) f^{\prime}(h)-w_{\mathrm{i}}-c^{\prime}(t)=0 \text { if } t>0 ;
\end{aligned}
$$

It is not difficult to see that a firm with a higher $i$ is more likely to reimburse tuition for its employees under reasonable assumptions. 
Instead of providing tuition reimbursement to encourage employees to increase their human capital, a firm could hire a new employee with the same level of human capital, say, the same as $h=h_{0}+t$ and dismiss the original employee with $h_{0}$. Suppose the cost of doing so is $r$. The profit level of a firm $i$ in this situation is

$$
m(0, i) f(h)-w_{\mathrm{m}} h-r,
$$

where $w_{\mathrm{m}}$ is the market wage. By the first order condition of optimization with respect to $h$, we have the following condition held,

$$
w_{\mathrm{m}}=m(0, i) f^{\prime}(h) .
$$

Firm $i$ compares these two schemes -- tuition assistance to improve the human capital of current employees v. hiring new employees. The firm chooses the more profitable one to implement. Let $D$ denote the difference of the two levels of profit,

$$
\begin{aligned}
& D=m(t, i) f(h)-w_{\mathrm{i}} h-c(t)-\left[m(0, i) f(h)-w_{\mathrm{m}} h-r\right] \\
& =[m(t, i) f(h)-m(0, i) f(h)]-\left(w_{\mathrm{i}} h-w_{\mathrm{m}} h\right)-(c(t)-r)
\end{aligned}
$$

The wage rate $w_{\mathrm{m}}$ is also the one faced by employees in firm $i$ if they choose to quit after taking the tuition reimbursement. To prevent quitting, the wage rate $w_{\mathrm{i}}$ should be higher or equal to $w_{\mathrm{m}}$ This means the wage rate for current employee should be at least equal to or greater than that for a new hire with the same human capital level. The reason here is that current employees have accumulated some firm-specific human capital than the new hires.

It is easy to see that if the gain in productivity $m(t, i) f(h)-m(0, i) f(h)$ is high enough such than the cost $c(t)-r$, which is true with appropriate parameters, then $D>0$ so that the firm will choose to provide educational support to current employees instead of hiring new ones. And the 
wage rate in this case is not lower than the market rate. Accordingly the turnover rate should be lower because employees have no incentive to quit. Further, the rate of involuntary turnover is also lower because firms do not need to layoff current employees and hire new ones. The comparative statics show that $D$ increases with the initial human capital $h_{0}$, which implies a positive correlation between $h_{0}$ and tuition reimbursement $t$.

We can examine the extent to which tuition assistance programs affect the ability to hire better workers as well as employee outcomes that are seen as indicating the presence of better matches.

\section{The Data:}

The ideal data for this study would be longitudinal data on individuals who use tuition assistance that includes their wages and their marginal productivity in order to measure the margin between the two before and using tuition assistance. Such data would have to include controls for employer characteristics and practices, and marginal productivity data has to be measured at the firm. No such data exist - there are not even any individual-level data on the use of tuition assistance. What we do have is data about employers, their use of tuition assistance and other practices, and average characteristics of their workforce including wages. The National Employer Survey II administered by the U.S. Bureau of the Census provides such information. The survey was conducted in August of 1997 (NES II) via Computer Assisted Telephone Interviewing (CATI). The sampling frame was drawn from the Standard Statistical Establishment List, arguably the most comprehensive list of establishments available. Public sector employees, not-for-profit institutions, and corporate headquarters were excluded from the sample. Although the survey excluded establishments with less than 20 employees (which 
represent approximately 85 percent of all establishments in the U.S.), the sampling frame represents establishments that employ approximately 75 percent of all workers (because most workers are employed in larger establishments). The survey over-sampled the nation's largest establishments and those in the manufacturing sector. Weights were constructed for the data by the Census to approximate the true distribution of establishments (by size and industry) in the economy. The target respondent in the manufacturing sector was the plant manager and the local business site manager in the non-manufacturing sector.

The sample for the NES II Public Use File used here has approximately 3,000 completed interviews that comprise a representative sample of the United States. The usual reason given by employers as to why they would not participate in the survey was that they did not participate in any voluntary surveys or were too busy to participate. Probit analysis conducted by Lynch and Black (1995) of the characteristics of nonrespondents from the initial NES survey in 1994, a similar sampling frame, indicates that there was no significant pattern at the two-digit industry level in the likelihood of participating in the survey. The only differentiating characteristic of establishments less likely to participate was that manufacturing establishments with more than 1000 employees, 0.1 percent of the sample, were less likely to do so.

The survey asks a series of questions about employer practices with respect to issues like recruiting, the terms and conditions of employment, and - most important - whether the employer provided tuition assistance. Many of the questions collect information about practices for five separate occupational categories: managers and professionals, supervisors, technicians, office/clerical/sales/and customer support, and production workers. Observations are removed from the analysis when data for any variable used in it is missing in order to keep sample sizes 
the same for all coefficients in the analysis. As a result, sample sizes tend to fall the more variables used and will differ across models.

Information about tuition assistance comes from the following question, "Do you reimburse the cost of tuition for an approved course for a. managers and professionals; b.supervisors; c.technical and technical support; d.office, clerical, sales; and e.customer service/production workers?"7 No doubt other information about tuition assistance would be interesting as well, such as how much assistance the employer provides or what kind of restrictions are put on the courses for which reimbursement can be received. But the basic issues concerning tuition reimbursement raised earlier all turn on why employers provide any such assistance, not how much they provide or how tightly they restrict it, and those issues can be addressed with information from this question.

Table 1 provides some simple descriptive information about the incidence of tuition assistance at the establishment level and how it varies by industry and by the size of the establishment. Perhaps the most remarkable statistic is simply how wide spread tuition assistance is, mirroring the results of earlier surveys noted above. Eight-eight percent of establishments say they reimburse tuition for approved courses, a figure roughly in the middle of the estimates from earlier ad hoc surveys. In some industries, the practice seems close to universal. The fact that so few establishments do not provide assistance limits the variance in this variable. Fortunately, the power of statistical tests is based not on the percentage of observations that vary, which is small (only 12 percent not providing tuition), but on the absolute number in the smallest cell (i.e., the smaller of the "yes" or "no" response), which is relatively

\footnotetext{
${ }^{7}$ The question does not ask about college course work per se, but the issues would be identical if the responses included secondary or high school education, which provide equally general skills. Virtually all part-time secondary education is free, including evening schools and General Education Degree programs (GED's), though, and the word "tuition" seems associated with post-secondary programs.
} 
large (181 in the survey). Variables with small cells are not a problem when used as independent variables, as used here, as long as they are not collinear with the other predictor variables.

\section{Table 1 Here}

The other variables used in the analyses that follow include a range of control variables based on characteristics of the establishments, such as their industry and size, and characteristics of their workforces, as well as information about specific employment practices related to the arguments above. These variables, their means and standard deviations, are provided in Table 2 and are discussed below in the context of the analyses where they are used.

Table 2 Here

\section{Analyses:}

Before examining the hypotheses outlined above, I consider a simple check on the usefulness of the data with respect to the question about tuition reimbursement. Presumably tuition reimbursement as an employer policy matters if it causes employees to undertake more education than they otherwise would. It is difficult to argue with the conceptual notion that reducing the price of education should increase employees' use of it, although one might imagine scenarios where policies of tuition reimbursement may not work (e.g., employers may restrict the use of their policies so tightly that the policies have little effect). The arguments and hypotheses presented above, though, are based on the assumption that at least some employees actually use these policies to increase their level of education beyond what it otherwise would be. And a positive relationship between tuition reimbursement programs and the educational outcomes of employees would make us much more sanguine about that assumption as well as about the usefulness of the data. 
It is not obvious from prior research exactly how one should model the relationship between tuition assistance and the educational attainment of an employer's workforce. One complication is that tuition assistance may well affect the overall level of education in a workforce by attracting applicants who already have more education, an issue examined explicitly below. Indeed, the level of education that workers have when they are hired may be the most important component of average education levels in the workforce. However, we would like to examine how tuition assistance affects the educational attainment of current employees, that is, whether it leads to additional education after they are hired. ${ }^{8}$ Fortunately, the NES asks employers not only about the average educational level of their workers but also about the average educational level of new hires. By examining the relationship between tuition assistance programs and average education levels while controlling for the average education of new hires, we can get a reasonably accurate sense of whether such assistance affects the educational levels of current employees. Because these measures aggregate from the attributes of individual employees, it seems reasonable to include demographic characteristics of the employees as control variables.

(6) I estimate an equation of the form: $\mathrm{Ed}_{\mathrm{i}}=\alpha+\mathrm{T}_{\mathrm{i}} \beta+\mathrm{X}_{\mathrm{i}} \gamma+\varepsilon_{\mathrm{i}}$, where we are estimating the causal effect of T, tuition assistance, on average education levels, Ed, and where $\mathrm{X}$ denotes a vector of factors that may affect educational attainment but are not related to the central hypothesis. The specific variables included as controls in $\mathrm{X}$ are industry, employment size (by category), manufacturing as a category, the percentage of the

\footnotetext{
${ }^{8}$ The complication here in sorting out heterogeneity associated with recruitment is that policies of tuition reimbursement may also attract applicants who are more interested in getting additional education. Even controlling for the level of education of recruits therefore does not completely control for the effects of recruitment on total educational attainment. On the other hand, attracting applicants more interested in education would be a crucial outcome of tuition assistance policies. Sorting out how much of the effect is
} 
workforce who are women and the percentage who are minorities, the distribution of employment by occupational category, and - most importantly - the average educational level of new hires.

The results of simple OLS regressions are reported in Table 3. The relationship between average education levels and tuition assistance programs, other things equal, is positive and significant, although the significance declines once controls for industry and employment size are added. These results are supportive of the notion that tuition assistance does influence the educational level of workers once they are hired. One could also use these coefficients to calculate something about the magnitude of education that workers receive as a result of these plans if one had good data on the percentage of workers across establishments who have ever used of tuition assistance, information that is unfortunately unavailable. If we assume that 10 percent of current employees have used them (the figure at one of the employers discussed earlier), then a coefficient of approximately 0.15 implies that those employees who have used the plan have on average 1.5 years more education as a result.

Table 3 Here

Evidence for Selection: A first step in considering the model described earlier is to see whether tuition assistance is associated with hiring more qualified applicants. There may be a wide range of attributes associated with better quality applicants, and no doubt it would be interesting to explore many of them. But the attribute that has arguably been seen as most important, particularly in human capital models, is the educational level of new hires. Education levels may also serve as a proxy for other desirable characteristics, such as persistence and plans would go beyond the limits of these data, however. 
general cognitive ability, that also raise performance. If applicants with more education are also ones with a greater interest in further education, then we might expect tuition assistance plans to be especially attractive to such applicants. We test whether the average education of new hires, controlling for other characteristics, is higher at establishments that offer tuition assistance with a simple model where the average education level of new hires is regressed against the incidence of tuition assistance plans:

(7) $\operatorname{HEd}_{i}=\alpha+\operatorname{Tr}_{i} \beta+X_{i} \gamma+\varepsilon_{I}$ where the average education level of new hires is a function of the incidence of tuition assistance plans and a vector of control variables which includes the distribution of employment by occupation, the percentage of workers who are women and who are minorities, industry, establishment size, manufacturing as a category, and, most important, the establishment's annual expenditures on recruiting new employees expressed as a percentage of labor costs. ${ }^{9}$ Such expenditures are a good measure for other efforts that may attract better quality applicants to the establishment.

OLS results in Table 4 suggest that there is a positive relationship between tuition assistance and the education level of new hires. Tuition plans, therefore, may help employers attract a more educated and better quality pool of workers. ${ }^{10}$

Table 4 Here

\footnotetext{
${ }^{9}$ In equation 6 , it is clearly important to control for new hire education when examining whether the average education of current workers is higher because new hire education so clearly influences average education. It is not at all clear how the average education of the workforce should affect the average education of new hires, however, except in a spurious sense.

${ }^{10}$ One issue is whether average education levels at each establishment should be included as control variables. While such levels may well send signals affecting who applies at that establishment, the empirical problem is that new hire education and average education are endogenous for the reasons noted earlier. One attempt around that problem is to regress average education on new hire education and use the residual as an independent variable in a subsequent equation modeling new hire education. The results of that exercise, available on request, lead to positive and relationships with tuition assistance of roughly the same size and of greater significance as those reported here. Results by occupation find the size of the manager and supervisor coefficients essentially the same as those in Table 4, considerably
} 
Do employees pay for tuition? The next step in the analyses is to examine relationships with wages. The model and evidence above suggests that because more productive workers come to establishments that offer tuition assistance and that information about their ability is private, employers can earn a margin while paying market wages. Evidence that wages are at or above market levels, other things equal, would be consistent with the view that workers are more productive in establishments where tuition assistance is offered. Wages below market levels, on the other hand, would be consistent with the most common explanation for general skills training, that workers pay for it through below market, training wages. The test is based on examining a simple wage equation of the form:

(8) $\mathrm{W}_{\mathrm{i}}=\alpha+\mathrm{T}_{\mathrm{i}} \beta+\mathrm{X}_{\mathrm{i}} \gamma+\varepsilon_{\mathrm{I}}$ where the intent is to model the relationship between tuition assistance $\mathrm{T}$ on wages $\mathrm{W}$ while controlling for a vector of other factors that may affect wages $\mathrm{X}$.

Control variables include the average education levels of the workforce (aggregated by each occupational group), the distribution of employment across those occupational groups, whether the establishment's employees are represented by a union, the industry and size of the establishment, the percentage of the workforce who are women, and the percentage who are minorities. Although the data used here are cross-sectional, that would appear to be less of an issue than might typically be the case because the hypotheses being considered is not necessarily causal: Independent of which came first, tuition plans or below-market wages, once these plans exist, are they paid for by holding wages below market levels?

The results of this wage equation for establishment wages are presented in Table 5. Overall, the model compares well in terms of explanatory power to a typical individual-level model (a 
standard human capital wage equation using Current Population Survey data, e.g., explains roughly a third of the variance in wages across individual workers).

Table 5 Here

The results show a positive and significant relationship between wages and tuition reimbursement plans. Because the model controls for workforce education levels, it is not the case that the higher wages can be attributed to the fact that tuition assistance plans raise education levels. The finding of a wage premium associated with tuition assistance plans is inconsistent with a model where wages are held below market rates either before, such as apprentice or training wage arguments, or after workers received tuition benefits. Other things equal, wages would have to be lower on average if employers were paying for tuition assistance by holding wages below market levels (if wages were lower at some point but offset by higher wages at another, the employer would have no margin from which to fund tuition assistance). The finding is consistent, however, with a model where marginal productivity is higher than market wages. Indeed, above average productivity is required for that result. Exactly why employers would set wages above market levels in these firms is something of a puzzle, though, not predicted by the model above. Rent-sharing in order to improve retention and keep morale high is one explanation; another is that some of the information about the superior productivity of these workers is public and affects their market wages; some omitted variable (e.g., the jobs are more demanding) is always a concern as well. It is impossible to sort out these explanations with the data available here.

A different argument from the prior literature noted earlier makes an explicit assertion about the direction of causation in the relationship between wages and tuition assistance. It asserts that the presence of compressed wage structures provides the opportunity to introduce 
and recoup investments in college education by holding down wages after receiving education. One needs longitudinal data before and after the introduction of tuition assistance plans for a truly accurate test, and the cross-section data available here can at best provide only suggestive evidence about that hypothesis.

In order to identify those situations where wage structures are compressed and below market levels, I first calculate the residuals from the wage equation (2) (but in this case excluding the tuition assistance variable from that equation) and use them as a measure of the extent to which wages are compressed or held below comparable rates elsewhere. Those residuals are then used to predict the incidence of tuition assistance plans. Wage residuals make it easier to interpret the coefficient as a test of the depressed wage argument.

(9) I estimate a model of the form: $\mathrm{T}_{\mathrm{i}}=\alpha-\mathrm{Wr}_{\mathrm{i}} \beta+\mathrm{X}_{\mathrm{i}} \gamma+\varepsilon_{\mathrm{I}}$ where the incidence of tuition assistance is estimated as a function of average wage residual at that establishment when controlling for a vector of other factors $\mathrm{X}$ that may affect tuition assistance. In addition to controls for industry and size, I also include a measure counting up the number of employee benefits offered at each establishment from a standard list of thirteen in the NES on the grounds that tuition assistance may operate as another form of employee benefit. Union coverage and the average education levels of new hires are included as other factors that affect market wages as well as industry, manufacturing as a sector, and average size control variables.

The results of Probit analyses, also presented in Table 5, indicate that wage residuals are positively related to the incidence of employer-provided tuition assistance programs. Although equation 9 is clearly not the same as equation 8 , it would have been surprising given the crosssectional nature of the data if the results were qualitatively different. Wages below prevailing 
levels at other employers do not seem to be driving the use of tuition reimbursement plans. In fact, the opposite appears to be true: Higher wages seem to be associated with the incidence of these plans. $^{11}$

One issue with establishment-level data such as these concerns the possibility of weighting the observations in the analyses based on their probability of appearing in the sample. OLS inconsistency can arise if the probability that a given observation in the population is included in the sample is related to the dependent variable such that the expected value of the product of the independent variables and the error term (conditional on being included in the sample p) is not equal to zero. That probability is interpreted as the inverse of the weight associated with that observation. WLS is a common choice if OLS is not consistent. But the drawback to WLS is that it can have a high variance due to the large variation in weights, variation that may have nothing to do with the bias in OLS. In this situation, the weights were generated by Census to make the data more representative of the population of all establishments and vary by industry and size of establishment. Because establishment employment in particular ranges from 20 to over 5000, the weights may have a large variation.

Hausman tests between OLS and WLS are performed on the results outlined below as an initial test of the consistency of OLS. For the OLS results presented in Tables 3 and 5, the coefficients of OLS and WLS are virtually identical. In Table 4, the differences between the two are significant. But this difference might be the result of the large variance in WLS rather than

\footnotetext{
${ }^{11}$ The coefficients by occupation are essentially the same in terms of magnitude for (ln) wages as that in Table 5 but were insignificant for managers. For the equation with wage residuals, the coefficient was virtually twice as large (1.33) for production workers and roughly half as large (.27) for supervisors. For coefficients were roughly similar for managers (.52), office workers (.78), and technicians but were insignificant for supervisors and technicians. The residual equation is the only one in the analyses here where tuition assistance is the dependent variable and where the small percent of "yes" responses might conceivably affect the analysis. But because there are a relatively large number of such responses (117)
} 
the bias of OLS. The 2STEP method proposed by Magee et al. (1998) is designed to address this situation and is used here. The results, presented in the Appendix, show that the 2STEP coefficients of interests are almost the same as the OLS in the sense that they have the same sign and significant levels. Thus, the unweighted results presented here seem appropriate. (There is no corresponding method for assessing the appropriateness of weights for logit and Tobit regressions, although the 2 STEP above when applied to those regressions also suggests no difference between the weighted and unweighted results.)

Tests of Employee Turnover: The next test is to see whether these plans are associated with lower levels of employee turnover, the proxy here for tenure. Turnover and employee tenure are not the same, of course. Average tenure can be affected by hiring rates as well as by employee quits (including retirements) and dismissals/layoffs. Quits and dismissals are the mechanisms behind turnover. They are also the mechanisms associated with the model above where both quits and dismissals should be lower where better quality workers self-select and stay with the firm longer to make use of tuition assistance. Employee turnover is made up of voluntary turnover (employee quits) and involuntary turnover (dismissals and layoffs) and is measured by the percentage of the workforce that leaves their employer in a given year. The NES II does not measure employee tenure but does report both measures of turnover by establishment, and they are combined here into a single turnover measure. Employers may pay higher wages in order to reduce turnover, but the hypothesis presented above suggests that workers will stay longer to make use of tuition assistance and predicts that turnover should be lower even independent of higher wages.

given the sample size of 963 , there are a reasonable number of such observations per independent variable. 
There is a large literature on employee turnover using the individual as the unit of analysis, but there is not a large literature to use as a guide in modeling employee turnover at the employer level. Cappelli and Neumark (2001) build such a model, and it is the basis for the analysis here.

(10) I estimate a model of employee turnover of the following form: $\operatorname{Turn}_{i}=\alpha+T_{i} \beta+$ $\mathrm{X}_{\mathrm{i}} \gamma+\varepsilon_{\mathrm{I}}$ where average annual turnover (Turn) is regressed against the incidence of tuition assistance and a vector of control variables that includes industry and manufacturing sector, size, average education levels, the distribution of employees across occupational categories, the percentage of women and the percentage of minorities, union coverage, and average wages, a factor seen as crucial in many prior studies of turnover. Additional control variables found useful in the Cappelli and Neumark (2001) study -on-the-job training (average time to become proficiency), the extent of teamwork, the amount of time needed to fill a typical vacancy, the number of candidates interviewed (measures of recruiting selectiveness), and the use of "benchmarking" as a technique to learn best practices from other organizations - are added as well. These variables are described in Table 2. Because turnover is measured as a percentage and, in some establishments, turnover rates are at or near zero, I use Tobit estimation techniques to correct for possible left-censoring of the data.

\section{Table 6 Here}

The results presented in Table 6 find a negative relationship between tuition assistance plans and employee turnover in all of the specifications. (Column 2 examines the equation without wages to see whether the relationships change: we know from prior research that wages drive turnover and from the results in Table 5 that wages covary with the incidence of tuition plans.) Analyses conducted separately for voluntary turnover and involuntary turnover, available 
on request, indicate that the relationships with tuition are always negative and strongly significant for involuntary turnover regardless of specification; the relationships for voluntary turnover, in contrast, while always negative, are more sensitive to specification. The overall pattern of results suggests that tuition assistance plans are associated with lower rates of turnover even independent of any wage effects. While self-selection arguments may cause employers to raise wages to reduce turnover, there is also evidence for a simple efficiency wage-type explanation, that employees stay longer to use the tuition assistance.

Alternative Interpretations: In all analyses, there is the possibility that other factors omitted from the model are explaining the results, omitted variables that are correlated with both the dependent variable and the relevant independent variables. Because there are no other systematic studies of tuition assistance plans, it is difficult to generate a list of what practices and policies might be correlated with them and with the independent variables above. Two may be worth investigation, however. The first, which relates only to the turnover results, questions whether some form of back-loaded or deferred compensation is the true cause of lower turnover for establishments that use tuition assistance. Under this explanation, employers who use tuition assistance also back-load compensation as a way to retain employees. Employers still have to be earning a return on the tuition investment in order to have an incentive to retain these workers because back-loading compensation per se does not generate a margin. ${ }^{12}$ But it would represent an alternative to the efficiency wage argument that workers are staying in order to use the tuition assistance benefit.

\footnotetext{
${ }^{12}$ Workers will obviously not remain if an employer holds their wages below market levels and then simply pays back the difference (or worse some fraction) in the future. If the argument is that employers hold down wages while tuition assistance is being used and then later pay workers the marginal product of their education, this is identical to the apprenticeship model described earlier. For the reasons noted there, it seems virtually impossible to use with tuition assistance.
} 
We can and do test the back-loaded compensation hypothesis empirically. While it is very difficult to establish the extent to which wages in any context are back-loaded, the most obvious form of such arrangements are pension plans. Is it the case that employers who use tuition assistance plans also use pension plans? The data used here do include whether establishments had pension plans. It would of course be helpful to know the details about these plans, information that is unfortunately not available. The correlation between having tuition assistance plans and pension plans is only 0.05 , however. And when pensions are added to the turnover equation, the results are unchanged. ${ }^{13}$

A second alternative hypothesis, which relates to the wage and turnover results, questions whether employers who use tuition assistance are also making greater investments in training. If so, training could be causing wages to be higher (rent sharing) and employees to stay longer (match quality). The argument that training and education may be complements in terms of generating productivity is well-established, but it is not so obvious that employers care about the source of education when making investments in training: specifically, why would they invest more in training when education was provided by tuition assistance programs as opposed to when employees paid for it themselves?

Nevertheless, we can also test this hypothesis. The NES data includes a measure of average hours of training per year for each establishment. Its correlation with the incidence of tuition assistance in these data is actually negative, -0.16 , suggesting the reasonable interpretation that the postsecondary education provided through tuition plans might be a

\footnotetext{
${ }^{13}$ I estimated various turnover models including the pension variable. When included with other employee benefits, for example, the pension coefficient was -0.28 and S.E. 5.84. In all cases, the tuition assistance variable remained strongly significant, never less than: coefficient -2.9 and S.E. $=1.5$.
} 
substitute for at least some employer-provided training. ${ }^{14}$ Including training does not change the relationships with tuition assistance in any important way in the wage or turnover equations. ${ }^{15}$

A final, alternative explanation for these results turns not on potential omitted variables but a different explanation for the employee responses to tuition assistance. Could it be a "gift exchange" (Akerlof 1981) in the sense that the tuition assistance benefits are seen by employees as a gift that generates a sense of obligation on their part and, in turn, leads to greater attachment/lower turnover? Because such an explanation turns on how workers interpret this benefit and what is going on inside their heads, it is essentially impossible to test it or differentiate it empirically from more rational self-interest explanations without very sophisticated experimental data. But there are logical grounds for thinking that tuition assistance is unlikely to generate much of a gift-exchange response. First, if an employer truly wanted to generate reciprocity-based loyalty through some gift exchange, they would choose a mechanism that looks more like a gift: Tuition assistance involves considerable effort and initiative on the part of the worker, unlike virtually all other benefits. It is also common enough that it is less likely to be seen as unusual - if it is typical and expected, can it be a gift? - and cannot be used

\footnotetext{
${ }^{14}$ The training variable retained a negative sign, although rarely significant, in preliminary models estimating the incidence of tuition assistance. There may be good institutional reasons for a negative relationship between training and tuition assistance. Under the U.S. Fair Labor Standards Act, employers who require that their covered employees (so-called "non-exempt" workers) receive training - even general skills training where the employee benefits -- must pay the full costs of such training, including the wages of those being trained. Employers can avoid that requirement by encouraging their workers to take skills training in the form of course work at colleges through tuition support. In this case, the employer may only be paying a portion of the tuition and other direct costs of these courses, and employees may be attending classes and doing homework on their own time. The employee's share of the investment is therefore much greater. Presumably employers could offer optional training in house and ask the employees to pay, but it may be less complicated to essentially outsource the operation and make it appear more like a benefit and less like a cost. It may also be cheaper to essentially outsource some skills training to colleges, especially community colleges and state-supported institutions where tuition and other direct costs are substantially subsidized through taxes.

${ }^{15}$ The tuition coefficient in the wage equation falls trivially but retains the same level of significance ( 0.52 S.E. $=0.22$ ). In the turnover equation, the tuition coefficient becomes slightly larger and trivially more significant $(-4.42$ S.E. $=2.07)$.
} 
until an employee has already put in some time in the organization. Employees also know about it when they sign on with the employer. Second, if tuition assistance could indeed generate this sense of loyalty, then presumably so would every other employee benefit including virtually everything that employers do for employees. If so, then there would be no unique behavior associated with tuition assistance. "Gift exchange" if it existed would simply be an attribute of being employed.

\section{Conclusion:}

Although the results of the above analyses are perhaps more suggestive than definitive of an answer as to why employers provide tuition assistance to their employees, they point to some reasonably clear conclusions. Employers must generate the resources to pay for these plans somehow. The institutional evidence suggesting how these plans work in practice makes it difficult to believe that wages are artificially held down while employees use them. And the evidence of wage premia associated with their use conflicts with the simple explanation that tuition assistance is paid for by holding wages below market levels through apprenticeship or training wage arrangements. Instead, the results appear more consistent with the view that workers who use tuition assistance have productivity that is above market levels. One reason for their greater productivity might be their better quality when hired, as the above results indicate. Employers can therefore pay the market wage and still earn a margin to recoup tuition assistance costs, although exactly why they are paying a wage premium remains something of a puzzle for future research. Turnover is lower, even independent of wage premia, and that result seems consistent with the view that workers stay with firms longer in order to make full use of tuition assistance plans. The fact that turnover is lower helps the employer pay for tuition benefits by 
earning a margin longer. Lower turnover in itself is a source of cost savings for employers by reducing search and hiring costs.

The fact that tuition assistance plans appear to be so common raises the question as to whether effective self-selection can be going on. One shortcoming of the data used here is that it only captures whether employer have tuition assistance and not the characteristics of what they offer. There is considerable and important variation across these plans with respect to how well they support employee education, as the descriptive data presented earlier suggests. Some meet only a fraction of the costs and are limited to a narrow range of job-specific courses while others cover virtually the entire cost of post secondary education, even for degrees unrelated to current jobs. As a practical matter, therefore, worker self-selection may be driven by the characteristics of plans and not simply whether an employer has one. If every employer had identical plans, of course, there would be no selection effects, although it might still make sense to have tuition assistance. They could represent an equilibrium employment condition, much like a market wage, that would make an employer stand out in a negative way if they did not offer them. Important questions for further research include examining how characteristics of tuition reimbursement plans affect the outcomes noted here and differentiating more clearly the source of benefit from these plans to employees. 


\section{Bibliography}

Acemoglu, D. and J. Pischke, 1998, Why do firms train? Theory and evidence, Quarterly Journal of Economics, 113(1), 79-119.

Acemoglu, D. and J. Pischke, 1999, Beyond Becker: Training in imperfect labor markets, Economic Journal, 109, F112-F142.

Akerlof, George. 1982. Labor Contracts as Partial Gift Exchanges. Quarterly Journal of Economics, 154, 79-83.

Altonji, Joseph G. and James R. Spletzer. 1991. Worker Characteristics, Job Characteristics, and the Receipt of On-the-Job Training. Industrial and Labor Relations Review, 45, 58-79.

Autor, D.H., 2001, Why do temporary help firms provide free general skills training? Quarterly Journal of Economics, 116, 1409-1448.

Babson, S.D., 1999, How to get financial aid for graduate education, Knight Ridder Tribune Business News, January 12.

Barron, J.M., M.C. Berger, and D.A. Black, 1997. On-the-Job Training. Kalamazoo, MI: Upjohn Institute.

Barron, J.M., M.C. Berger, and D.A. Black, 1999, Do workers pay for on-the-job training? Journal of Human Resources, 34 (2), 235-52.

Becker, G.S. 1964. Human Capital. Chicago: University of Chicago Press.

Bishop, J., 1996, What do we know about employer-provided training? Ithaca, NY: Cornell University Center for Advanced Research on Human Resources, working paper.

Bowlus, A.J., 1995, Matching workers and jobs: Cyclical fluctuations in match quality, Journal of Labor Economics, 13(2), 335-50. 
Bureau of the Census. 1994. Dollars for Scholars - Postsecondary Costs and Financing.

Washington, D.C.: Statistical Brief. U.S. Department of Commerce. Economics and Statistics Administration, Bureau of the Census.

Bureau of National Affairs (BNA), 1992a, Benefit policies, Bulletin to Management, February 12.

Cappelli, P. and D. Neumark. 2001. Do 'High Performance” Work Practices Improve Establishment-Level Outcomes? Industrial and Labor Relations Review, 54(1), 737-775.

Cappelli, P. and D. Neumark. 2001. External Job Churning and Internal Job Flexibility. NBER Working Paper.

Greenwald, Bruce. 1986. Adverse Selection in the Labor Market. Review of Economics and Statistics, 53, 325-347.

Hersch, J. and P. Reagan, 1990, Job match, tenure and wages paid by firms, Economic Inquiry, 28(3), 488-507.

Hewitt Associates, 1993, On Employee Benefits (Lincolnshire, IL.)

Hewitt Associates, 1998, Survey Findings: Design and Administration of Educational Reimbursement Plans (Lincolnshire, IL) .

Hudson, L., 2001, Demographic and Educational Trends in Postsecondary Education (Washington: National Research Council Manuscript).

International Foundation of Employee Benefit Plans, 1993, Results 1993-2: Educational Assistance in the Workplace (Washington, D.C.: IFEBP). , 2002. The Many Faces of Educational Benefits. (Brookfield, WI.)

Jaeger, D.A. and A.H. Stevens, 2000, Is job stability in the United States falling? Reconciling trends in the current population survey and the panel study of income dynamics. In D .Neumark 
(ed.). On the Job: Is Long-Term Employment a Thing of the Past? (New York: Russell Sage Foundation), 31-70.

Jovanovic, B. 1979. Job matching and the theory of turnover. Journal of Political Economy, 87 (5) 972-990.

Katz, E. and A. Ziderman, 1990, Investment in general training: The role of information and labour mobility, The Economic Journal, 100 (403) 1147-1159.

Lee, J.B. and S.B. Clery,1999, Employer Aid for Postsecondary Education” (NCES 1999-181).

(Washington, D.C.: U.S. Department of Education, National Center for Educational Statistics)

Leuvan, E., 1999, The demand and supply of work-related training: Evidence from four countries, Research in Labor Economics, (18)

Lynch, L. and S. E. Black. 1995. Beyond the Incidence of Employer Provided Training: Evidence from a National Employers Survey. Cambridge, MA: NBER Working Paper.

Magee, L., A. L. Robb, and J.B. Burbridge. 1998. On the Use of Sampling Weights When Estimating Regression Models with Survey Data. Journal of Econometrics, (84), 251-271. McCall, J. J., 1970, Economics of information and job search. Quarterly Journal of Economics, 84(1), 113-126.

Neumark, D., D. Polsky, and D. Hansen, 2000, Has job stability declined yet? New evidence for the 1990s. . In D. Neumark (ed.). On the Job: Is Long-Term Employment a Thing of the Past? (New York: Russell Sage Foundation), 70-111.

Simon, C.J. and J.T. Warner, 1992, Matchmaker, matchmaker: The effect of old boy networks on job match quality, earnings, and tenure. Journal of Labor Economics, 10(3), 306-30. 
Society for Human Resource Management (SHRM). Research: 2002 Benefits Survey. SHRM:

Alexandria, VA.

Stevens, M., 1994, An investment model for the supply of training by employers, The Economic Journal, May, 556.

Wilk, S., L.B. Desmarais and P. Sackett, 1995, Gravitation to jobs commensurate with ability:

Longitudinal and cross-sectional tests. Journal of Applied Psychology, 80(1), 79-85. 
Table 1:

Descriptive Statistics for Tuition Reimbursement

\begin{tabular}{|c|c|c|c|}
\hline & & Mean & Std. Deviation \\
\hline \multicolumn{4}{|l|}{$\underline{\text { size }}$} \\
\hline & Less than 50 & $\mid .854$ & .354 \\
\hline & $50-99$ & .821 & .384 \\
\hline & $100-249$ & .886 & .319 \\
\hline & $250-999$ & .827 & .378 \\
\hline & 1,000 or more & .857 & .351 \\
\hline \multicolumn{4}{|c|}{ Industry } \\
\hline & Food(20) \& Tobacco(21) & .639 & .487 \\
\hline & Textile(22) \& Apparel(23) & .651 & .482 \\
\hline & Lumber(24) \& Paper(26) & .721 & .452 \\
\hline & Printing \& Publishing(27) & .727 & .448 \\
\hline & Chemicals(28) \& Petroleum(29) & .842 & .367 \\
\hline & Primary metals(33) & .781 & .416 \\
\hline & Fabricated metals(34) & .882 & .325 \\
\hline & Machinery \& Inst. $(35,36,38)$ & .885 & .32 \\
\hline & Machinery \& Inst. $(35,36,38)$ & .882 & .325 \\
\hline & Other \& Misc. Man. $(25,30,31,32)$ & .897 & .306 \\
\hline & Construction $(15-17)$ & .842 & .366 \\
\hline & Transport. sves. $(42,45)$ & .808 & .397 \\
\hline & Communication(48) & .875 & .336 \\
\hline & Utilities(49) & .836 & .373 \\
\hline & Wholesale trade $(50,51)$ & .933 & .252 \\
\hline & Retail trade(52-59) & .905 & .295 \\
\hline & Finance(60-62) & .864 & .347 \\
\hline & Insurance $(63,64)$ & .881 & .326 \\
\hline & Hotels(70) & .973 & .164 \\
\hline & Business sves.(73) & .972 & .167 \\
\hline & Health Services $(80)$ & .853 & .359 \\
\hline \multicolumn{4}{|l|}{ Sector } \\
\hline & Manufacture & .865 & .342 \\
\hline & Non-manufacture & .809 & .393 \\
\hline
\end{tabular}

Correlation between Tuition Reimbursement, Manufacturing, And Size (obs=1494)

\begin{tabular}{|c|c|c|c|}
\hline & Tuition & Manufacturing & Size \\
\hline Tuition & 1.0000 & & \\
\hline Manufacturing & 0.0737 & 1.0000 & \\
\hline Size & -0.0018 & .0193 & 1.0000 \\
\hline
\end{tabular}


Table 2:

Variables, Means and Standard Deviations

Variable
Obs Mean Std. Dev.

\begin{tabular}{|c|c|c|}
\hline 1511 & .88 & .36 \\
\hline 1687 & 12.75 & 1.05 \\
\hline 463 & 13.28 & 1.13 \\
\hline 1024 & 32.40 & 43.63 \\
\hline 2696 & 7.42 & 10.76 \\
\hline 2928 & 16.10 & 29.86 \\
\hline 2935 & 20.04 & 31.11 \\
\hline 2903 & 2.58 & 2.67 \\
\hline 2955 & .77 & .42 \\
\hline 1420 & 31815.69 & 10282.8 \\
\hline 2799 & 15.37 & 22.45 \\
\hline 1742 & 43.93 & 4.48 \\
\hline 2943 & 20.26 & 36.35 \\
\hline 2855 & 6.97 & 1.94 \\
\hline 2693 & 3.19 & 3.13 \\
\hline 2557 & 6.71 & 8.29 \\
\hline 2934 & .38 & .49 \\
\hline 2736 & 2.56 & .82 \\
\hline 2898 & 57.00 & 42.89 \\
\hline
\end{tabular}

Tuition assistance

Whether reimburse tuition for approved courses

Education level

Average schooling for all employees

Average schooling for employees

hired in the last two years

Average number of training hours

each employee received last year

Work organization

Months to become fully proficient

Percentage of employees in self-managed teams

Percentage of employees in job rotation

Levels between bottom and top officials

Whether contribute to a pension plan

Average salary

Percentage of permanent workforce left voluntarily last year

Average hours worked per week

Percentage of employees covered by a collective-bargaining agreement

Number of employee benefit types

Number of weeks to fill a typical production employee's job opening

Number of candidates interviewed for each production employee's job opening

Whether undergone re-engineering within the past three years

Importance of education criteria in employee selection (the highest possible scale is 5)

Percentage of employees involved in regular meetings to discuss work-related issues 
$\underline{\text { Table } 3}$

OLS Estimates of Educational Attainment as a Function of Tuition Assistance

(1)

(2)

$*$ t-statistics 5\% significant

$* *$ t-statistics $1 \%$ significant

Table 4

OLS Estimates of Educational Levels of New Hires as a Function of Tuition Assistance

(1)

\begin{tabular}{lcl}
\hline tuition assistance & $.354(.140)^{* *}$ & $.225(.123)^{\wedge}$ \\
supervisors & $-.001(.011)$ & $.002(.010)$ \\
technical & $-.008(.008)$ & $-.008(.009)$ \\
clerical & $-.018(.007)^{* *}$ & $-.015(.008)^{\wedge}$ \\
production workers & $-.038(.006)^{* *}$ & $-.029(.006)^{* *}$ \\
women & $.001(.002)$ & $.00008(.003)$ \\
minorities & $-.004(.002)^{*}$ & $-.003(.002)$ \\
recruit-cost & $.023(.008)^{* *}$ & $.022(.012)^{\wedge}$ \\
constant & $15.40(.577)^{* *}$ & $-3.44(.069)^{* *}$ \\
Ind_type & not included & included \\
size & not included & included \\
sector & not included & included
\end{tabular}

$\begin{array}{lll}\text { Number of observations } & 322 & 322 \\ \text { R - Squared } & .4377 & .5674\end{array}$

\footnotetext{
* t-statistics 5\% significant

** t-statistics $1 \%$ significant

$\wedge$ t-statistics $10 \%$ significant
} 
Table 5:

\section{OLS Wage regressions as a Function of Tuition Assistance}

\begin{tabular}{lll}
\hline \multicolumn{1}{c}{$\begin{array}{c}(1) \\
\text { OLS Wage Regressions as a }\end{array}$} & \multicolumn{1}{c}{$\begin{array}{c}(2) \\
\text { Probit Estimates of Tuition Assistance } \\
\text { Function of Tuition Assistance }\end{array}$} \\
\hline as a Function of Wage Premium
\end{tabular}


Table 6

Tobit Estimates of Employee turnover as a Function of Tuition Assistance

\begin{tabular}{|c|c|c|c|}
\hline & (1) & (2) & (3) \\
\hline tuition assistance & $-4.25(2.01)^{*}$ & $-3.82(1.87)^{*}$ & $-3.49(2.09)^{\wedge}$ \\
\hline education & $-1.17(.946)$ & $-3.28(.837)^{* *}$ & $-2.09(1.00)^{*}$ \\
\hline $\ln ($ pay) & $-17.54(2.88)^{* *}$ & $\ldots$ & $-13.80(3.37)^{* *}$ \\
\hline supervisors & $-.190(.173)$ & $-.082(.160)$ & $-.246(.185)$ \\
\hline technical & $-.088(.107)$ & $-.073(.099)$ & $-.086(.109)$ \\
\hline clerical & $-.296(.118)^{*}$ & $-.221(.110)^{*}$ & $-.327(.122)^{* *}$ \\
\hline productionworkers & $-.127(.095)$ & $-.070(.086)$ & $-.158(.098)$ \\
\hline \%women & $.058(.036)$ & $.137(.038)^{* *}$ & $.044(.045)$ \\
\hline$\%$ minorities & $-.095(.030)^{* *}$ & $.086(.028)^{* *}$ & $.073(.031)^{*}$ \\
\hline proficient & $\ldots$ & $\ldots$ & $-.076(.061)$ \\
\hline recruit-time & $\cdots$ & $\cdots$ & $-.391(.267)$ \\
\hline \#candidates & $\ldots$ & $\ldots$ & $.014(.100)$ \\
\hline team & $\ldots$ & $\ldots$ & $-.009(.025)$ \\
\hline benchmarking & $\ldots$ & $\ldots$ & $-.377(1.51)$ \\
\hline union & $\ldots$ & $\ldots$ & $-.038(.021)^{\wedge}$ \\
\hline constant & $227.77(31.15)^{* *}$ & $65.05(15.74)^{* *}$ & $203.35(36.27)^{* *}$ \\
\hline Ind type & & included & included \\
\hline size & $\ldots$ & included & included \\
\hline sector & $\ldots$ & included & included \\
\hline No. of obs. & 1110 & 1336 & 1029 \\
\hline Pseudo R2 & .0127 & .0152 & .0189 \\
\hline
\end{tabular}

\footnotetext{
$*$ t-statistics 5\% significant

$* *$ t-statistics $1 \%$ significant

$\wedge$ t-statistics $10 \%$ significant
} 
Appendix: Correlation Matrix

| tuition meetings proficient team rotation levels work-hours

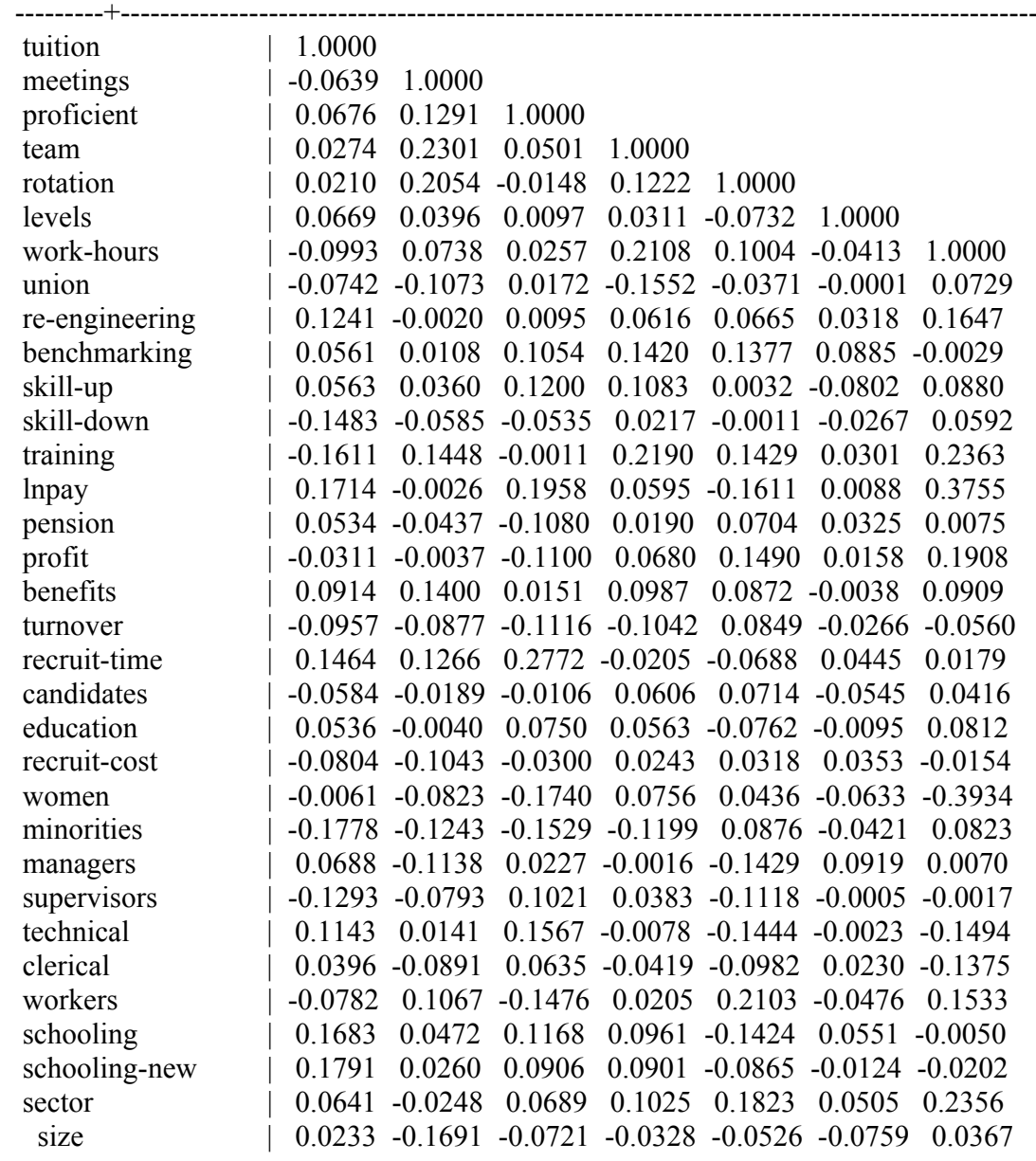

union re-engineering benchmarking skill-up skill-down training lnpay

\begin{tabular}{|c|c|c|c|c|c|c|c|}
\hline union & 1.0000 & & & & & & \\
\hline re-engineering & 0.0587 & 1.0000 & & & & & \\
\hline benchmarking & 0.0714 & 0.0741 & 1.0000 & & & & \\
\hline skill-up & 0.0120 & 0.1793 & 0.1545 & 1.0000 & & & \\
\hline skill-down & 0.0144 & -0.0105 & -0.0055 & -0.2015 & 1.0000 & & \\
\hline training & 0.0212 & 0.0013 & -0.0232 & 0.0807 & -0.0231 & 1.0000 & \\
\hline lnpay & 0.1440 & 0.0612 & 0.1473 & 0.2224 & -0.0558 & -0.0063 & 1.0000 \\
\hline pension & 0.1898 & 0.1385 & 0.0428 & 0.0663 & -0.0503 & 0.0928 & 0.0635 \\
\hline profit & 0.0423 & 0.1612 & 0.1344 & 0.0197 & 0.0280 & 0.0775 & 0.0983 \\
\hline benefits & 0.0549 & 0.1301 & 0.1955 & 0.1103 & 0.0035 & 0.1058 & 0.1832 \\
\hline turnover & -0.0772 & -0.0364 & -0.1315 & -0.0801 & 0.3025 & -0.0697 & -0.2698 \\
\hline recruit-time & 0.0827 & 0.0719 & 0.1003 & 0.1518 & -0.0935 & 0.0463 & 0.3435 \\
\hline candidates & 0.0671 & 0.0733 & 0.0302 & 0.1092 & -0.0181 & 0.2663 & 0.1334 \\
\hline education & -0.0067 & 0.0297 & 0.0784 & 0.1377 & 0.1299 & 0.0611 & 0.1628 \\
\hline recruit-cost & -0.1058 & 0.0053 & -0.0210 & -0.0122 & -0.0209 & 0.0752 & -0.0443 \\
\hline women & -0.2959 & -0.0578 & 0.0544 & 0.0083 & 0.0529 & -0.0608 & -0.4106 \\
\hline minorities & 0.0043 & -0.0419 & -0.0805 & -0.0762 & -0.0244 & 0.0883 & -0.1284 \\
\hline sectoragers & -0.1569 & -0.0399 & 0.0422 & 0.1027 & 0.0697 & -0.0210 & 0.2718 \\
\hline isors & -0.0757 & -0.0001 & -0.0647 & 0.0615 & -0.0170 & 0.0445 & 0.2819 \\
\hline & -0.1625 & 0.0149 & 0.0598 & 0.1108 & -0.0642 & -0.0165 & 0.2203 \\
\hline clerical & -0.0896 & -0.0525 & 0.0278 & 0.1088 & -0.0234 & -0.0448 & 0.0422 \\
\hline
\end{tabular}


\begin{tabular}{l|lllllll} 
workers & 0.2117 & 0.0386 & -0.0481 & -0.1728 & 0.0229 & 0.0326 & -0.3036
\end{tabular}

\begin{tabular}{l|lllllll} 
schooling & -0.1925 & 0.0591 & 0.0694 & 0.1641 & -0.1081 & -0.0296 & 0.4960
\end{tabular}

\begin{tabular}{l|llllllll} 
schooling-new & -0.1577 & 0.0136 & 0.0819 & 0.1076 & -0.1065 & 0.0435 & 0.4520
\end{tabular}

\begin{tabular}{l|lllllll} 
sector & 0.1699 & 0.0675 & 0.0045 & -0.1039 & 0.0066 & 0.0529 & 0.0194
\end{tabular}

\begin{tabular}{l|lllllll} 
size & 0.2262 & 0.1318 & 0.0708 & 0.0764 & -0.0603 & -0.0872 & 0.0693
\end{tabular}

| pension profit benefits turnover recruit-time candidates education

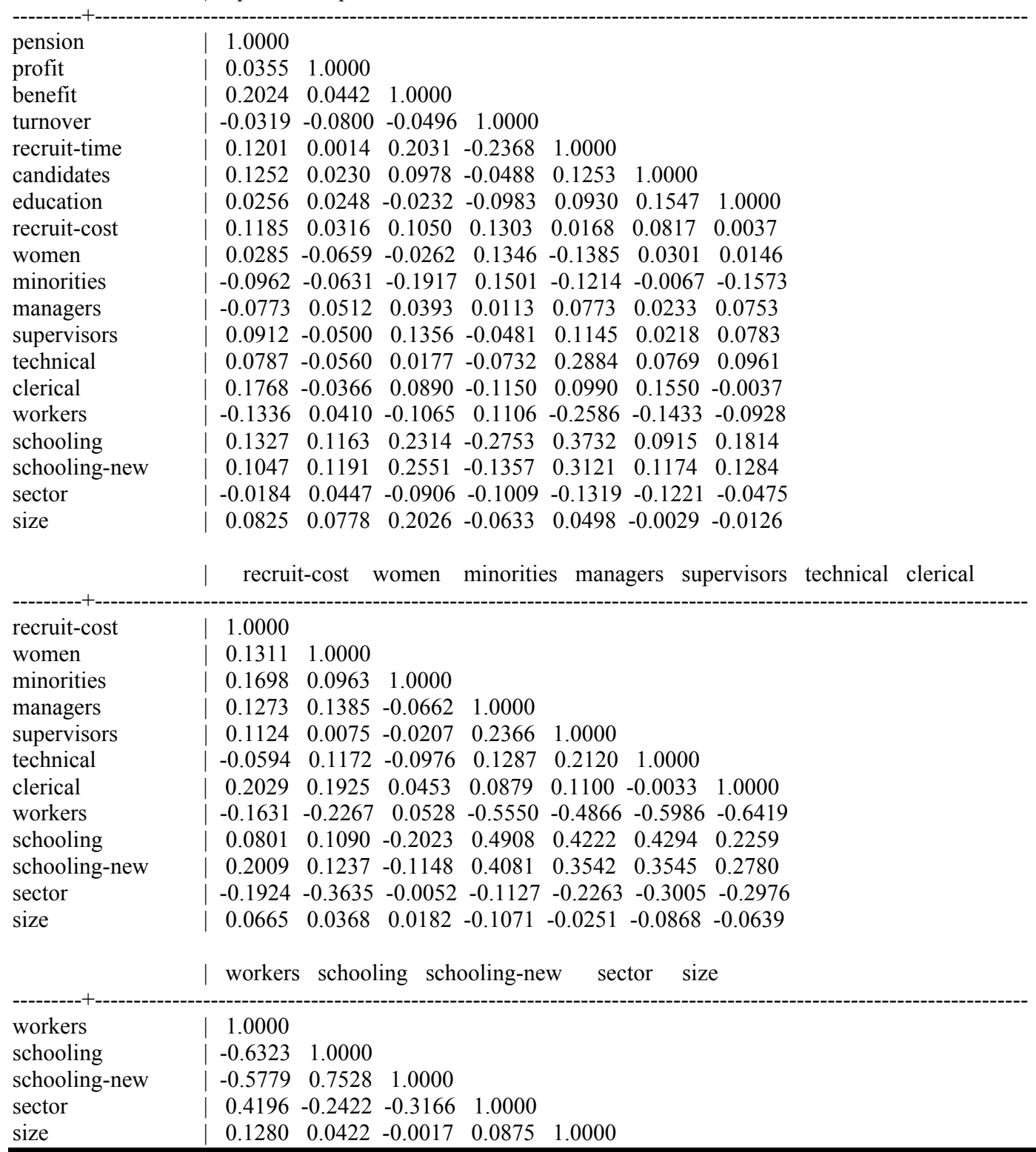

